\author{
Jana Juř́íková, Hung Duc Nguyen ${ }^{1}$ \\ Masaryk University, Faculty of Sport Studies, Department of Kinesiology, Brno, \\ Czech Republic
}

\title{
Eating habits in judokas
}

\begin{abstract}
Purpose The aim of the paper was to find out eating habits of judokas from judo club in Holešov and students of programme Special Education of Security Bodies who practise combative sports including judo in University Campus in BrnoBohunice. in the Czech Republic.

Design/methodology/approach: The questionnaire survey was attended by 66 judokas in total, out of which there were 34 male (52\%) and 32 female (48\%) respondents. Women aged 20-25 years (average age in female group was 19.34), men also aged 20-25 years (average age in male group was 22.24). The questionnaire was anonymous.

Research and practical limitations/implications: Majority of female respondents were students with non-sportive specialization, in men it is about a half $(41 \%$ of respondents). Majority of respondents were practiced judo as a self - defense technique - this answer was given by $55.9 \%$ of men and $59.4 \%$ of women. $26.5 \%$ of men and $21.9 \%$ of women always pay attention to well-balanced diet. The highest number of respondents claims that they always respect specific need for energy income $-61.8 \%$ of men and $84.4 \%$ of women. Merely $14.7 \%$ of men and $9.4 \%$ of women admitted that they do not consider specific energy income for sportspeople, and $61.8 \%$ of men and $84.4 \%$ of women reported that they consider it sometimes. Respondents who use nutritional supplements mostly prefer carbohydrate-protein conjugates - this option was selected by $70.6 \%$ of men and $75 \%$ of women. Most respondents do not use supplements with vitamins and minerals - this answer was given by $64.7 \%$ of men and $75 \%$ of women.
\end{abstract}

Originality/value: Most of respondents are interested in their nutrition. Many of them need some education from sports nutritionists.

Keywords: eating habits, athletes, judokas, energy intake, supplements, vitamins, minerals

\section{Introduction}

Combat sports are a discipline of sport in which the rivalry consists of direct encounter of two sportsmen, in the form of immediate influence on the body of the competitor with the purpose of the documentary evidence of one's own superiority.

\footnotetext{
${ }^{1}$ Ing. Mgr. Jana Juř́ková, Ph. D., jurikova@ fsps.muni.cz, bc. Duc Hung Nguyen, 442289@ mail.muni.cz
} 
The sports-fight relies among other things on the infliction of knocks (boxing, kick boxing, taekwondo), or the usage of throwing or grappling (wrestling, judo) (Kalina et al., 2003; Kalina, 2000; Boguszewski et al., 2013). Judo is modified form of the old Japanese martial art - ju-jitsu.

Judo can be practiced by men in every age, of different physique and different fitness level. Judo can be practiced by women too. It offers benefits to all: people of any age or body type can practice it. Many people start as early as age 5 and some continue to practice the art through their $70^{\prime}$ s. For many people, judo provides a means to improve their general fitness level by increasing strength, flexibility, conditioning, coordination, and balance. For others, judo instills a sense of selfconfidence, self-discipline, and self-control, all of which are necessary life skills. Parents like judo because it teaches their children discipline and respect. In addition to keeping its practitioners trim and fit, judo also provides people with invaluable self-defense skills (Pedro et Durbin, 2001).

The founder of judo Džigoro Kano, defined this sport in 1915 as the most effective way to utilize physical and mental energy (Hoare, 2009). The identity of combat sports and martial arts consists of the integration of three specific factors: pragmatic, utilitarian and mental. They influence on the psychophysical and moral education of a man. Therefore, sports and martial arts are much more than disciplines of sport. They are the form of the physical education, the defensive education and the philosophy (Kalina, 1997; Boguszewski et al., 2013).

\section{History of judo}

Judo history began in 1882 when Kano opened his small school and dojo in the Eisho-temple in Tokyo but a little work soon exposed the fact that judo was based on jujitsu which were based on kumi-uchi (samurai grappling) which was based on military sumo which was based on the Chikara kurabe of the ancient myths (Hoare, 2009).

As an educational method derived from the martial arts, judo became an official Olympic sport in 1964 (after being named as a demonstration sport at the 1940 Tokyo Olympicc Games which were cancelled due to international conflict). The International Judo Federation is composed of National Judo Federations and Continental Unions. Each National Federation must be recognized as the sole federation authorized to represent its country in international sporting bodies by its Olympic Committee, which itself is duly recognized by the International Olympic Committee (www.ijf.org; International Judo Federation Aims and Missions).

Nowadays, judo is an Olympic, weight class combat sport with high-level competition from the cadet (under 18 years old, Youth Olympic Games, World Championship) to the veteran (World Championship) age categories (Franchini et al., 2011a; Franchini et al., 2011b; Julio et al., 2011; Escobar-Molina et al., 2015).

Judo is the most popular Olympic combat sport practiced throughout the world (www.intjudo.eu). In combat sports, competitors are grouped in weight classes to ensure more aquitable matches, so that opponents of similar size and strength are paired against one another (Artioli et al., 2010). Athletes in other combat sports, 
including wrestling, taekwondo, jujitsu and karate, use rapid weight loss prior to competitions (Kiningham et Gorenflo, 2001; Kazemi et al., 2005; Brito et al, 2012; Malliaropoulos et al., 2017).

\section{Weight categories in judokas}

Judokas compete in categories based on their body mass in order to match athletes for body and size to limit the risk of injury (Franchini et al., 2012; Aloui et al., 2016). There are 7 categories for both of them senior male and senior female contestants - show in table 1 .

Table 1. Olympic weight categories for male and female judokas

\begin{tabular}{|c|c|}
\hline \multicolumn{2}{|c|}{ Olympic weight categories for male and female judokas } \\
\hline male & female \\
\hline \hline above $100 \mathrm{~kg}$ & above $78 \mathrm{~kg}$ \\
\hline up to $100 \mathrm{~kg}$ & up to $78 \mathrm{~kg}$ \\
\hline up to $90 \mathrm{~kg}$ & up to $70 \mathrm{~kg}$ \\
\hline up to $81 \mathrm{~kg}$ & up to $63 \mathrm{~kg}$ \\
\hline up to $73 \mathrm{~kg}$ & up to $57 \mathrm{~kg}$ \\
\hline up to $66 \mathrm{~kg}$ & up to $52 \mathrm{~kg}$ \\
\hline up to $60 \mathrm{~kg}$ & up to $48 \mathrm{~kg}$ \\
\hline
\end{tabular}

Source: Stubbs, 2009

This sport recognizes 67 take-down techniques, 29 immobilizing techniques and 19 strike techniques in total. These techniques differ depending on whether they focus on falls, fighting on ground, postures and throws, self-defence or advanced techniques. Each technique demands a particular physical strength, skills and speed. The founder of this martial art developed a ranking system distinguishing student (kyu) and master (dan) grades. There exist 5 student grades (in some countries 6) and 10 masters grades. A judoka who mastered techniques and skills of the particular grade wears a coloured belt - the colour is defined for each grade. Technical grades and their defined colours are given in table 2. 
Table 2. Technical grades and their defined colours of belts in judo

\begin{tabular}{|c|c|c|c|}
\hline Grade & Title & Belt & Colour \\
\hline $6^{\text {th }} \mathrm{kyu}$ & roko-kjú & white & \\
\hline $5^{\text {th }} \mathrm{kyu}$ & go-kjú & yellow & \\
\hline $4^{\text {th }} \mathrm{kyu}$ & ši-kjú & orange & \\
\hline $3^{\text {rd }} \mathrm{kyu}$ & san-kjú & green & \\
\hline $2^{\text {nd }} \mathrm{kyu}$ & ni-kjú & blue & \\
\hline $1^{\text {st }} \mathrm{kyu}$ & ik-kjú & brown & \\
\hline $1^{\text {st }}$ dan & Šo-dan & black & \\
\hline $2^{\text {nd }}$ dan & ni-dan & black & \\
\hline $3^{\text {th }}$ dan & san-dan & black & \\
\hline $4^{\text {th }}$ dan & jon-dan & black & \\
\hline $5^{\text {th }}$ dan & go-dan & black & \\
\hline $6^{\text {th }}$ dan & roku-dan & black or red-white & \\
\hline $7^{\text {th }}$ dan & šiči-dan & black or red-white & \\
\hline $8^{\text {th }}$ dan & hači-dan & black or red-white & \\
\hline $9^{\text {th }}$ dan & ku-dan & black or red & \\
\hline $10^{\text {th }}$ dan & džú-dan & black or red & \\
\hline
\end{tabular}

Source: http://www.judo-3.banda.cz/clanek/13982/pasky/

\section{Eating behaviours in judokas}

Regular participation in exercise and sports activities confers numerous health- and performance-related benefits that contribute to a reduction in chronic diseases and 
disabling conditions, increased longevity, and an enhanced quality of life (Garber et al., 2011; Maughan, 2014). The specific physiologic adaptations that occur with exercise activities depend on the frequency and duration of participation and the intensity of the sporting event. In general, the greater the product of the frequency, duration, and intensity of an exercise program, the greater the health- and performance-related benefits.

Torstweit et al. (2008) indicated that sporting facilities are usually full of opportunities to optimize athletic performance as well as body shape and size Athletes may feel pressured to improve performance and body weight at any cost. Hence, some athletes are most likely to use unhealthy methods of changing their body weight or lean body mass with the belief that this change will enhance peak performance (Costarelli at Stamou, 2009; Rosendahl et al., 2009; Fortes at Ferreira, 2011; Fortes at al., 2014).

Making weight is a very common practice among judokas. Immediately prior to a competition, contestants are sorted into 7 sexpecific weight categories (table 1), with the objective of ensuring equitable matches in terms of muscular strength and leverage (Artioli et al., 2009). Unfortunately, many judokas engage in rapid weight loss for a few days before competition in order to compete in a lower weight category and thereby increase their chances of victory (Artioli et al., 2009; Franchini at al., 2012). The tactics used include reduced ingestion of liquid, use of saunas, wearing impermeable plastic blouses and suits to increase sweating, a reduced overall energy intake and/or fasting prior to the weigh-in, and a selective reduction in the intake of carbohydrate or fat (Franchini at al., 2012). Some competitors resort to more aggressive tactics, such as forced vomiting (Filaire at al., 2007) and the ingestion of various appetite suppressants, laxatives and diuretics (Franchini at al., 2012; Aloui, 2016).

Weight management started to be a main concern in judo since the $1950 \mathrm{~s}$, when judo turned into a modern, international, and institutionalized sport, and weight categories were introduced in competitions (Villamón et al., 2004). Through decated, weight categories have been progressively established and increased for competition groups of different gender, age, and level of competition, placing the "weight issue" - i. e., the ways in which judo athletes face weight contro - in the core of competitive judo culture (Pettersson et al., 2013; Escobar-Molina et al., 2014).

\section{Material and methods}

Respondents were judokas from Judo Holešov team who practise within the area of Police College and High Police School of Ministry of the Interior in Holešov (Czech Republic) and students of programme Special Education of Security Bodies who practise combative sports including judo in University Campus in Brno-Bohunice (Czech Republic). The questionnaire was anonymous. The questionnaire survey was attended by 66 judokas in total, out of which there were 34 male $(52 \%)$ and 32 female (48\%) respondents. Women aged 20-25 years (average age in female group was 19.34), men also aged 20-25 years (average age in male group was 22.24). 


\section{Results and discussion}

Opening question focuses on the information whether respondents are professional judo competitions or they have other civil occupation. Figure 1 divides respondents according to this aspect.

Figure 1. Respondents according to their occupation or study

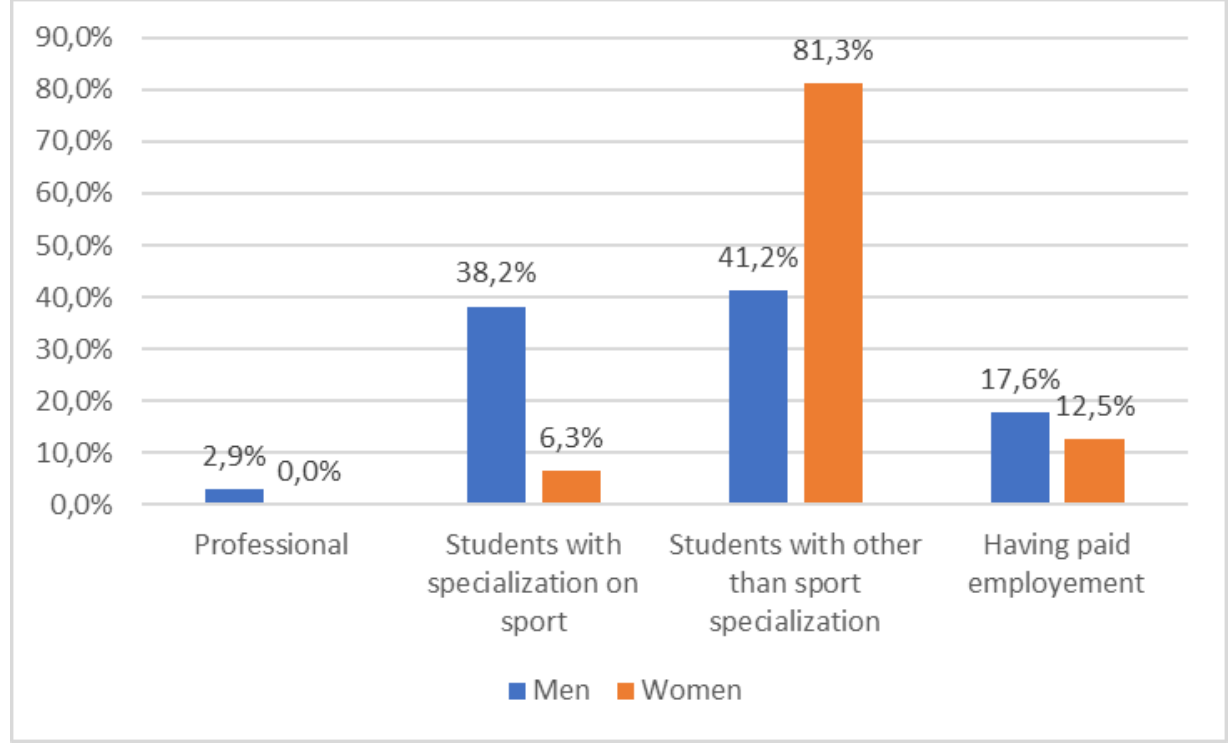

Figure 1. Respondents according to their occupation or study

Source: Study of authors

Majority of female respondents were students with non-sportive specialization, in men it is about a half ( $41 \%$ of respondents). Students with sport specialization were represented by $38.2 \%$ of men and $6.3 \%$ of women. $17.6 \%$ men and $2.5 \%$ women are working. Merely $3 \%$ of male respondents are professional judokas; in female group there were no professionals at all. 
Next question discovered technical level of examined judokas. Their answers are given in figure 2 .

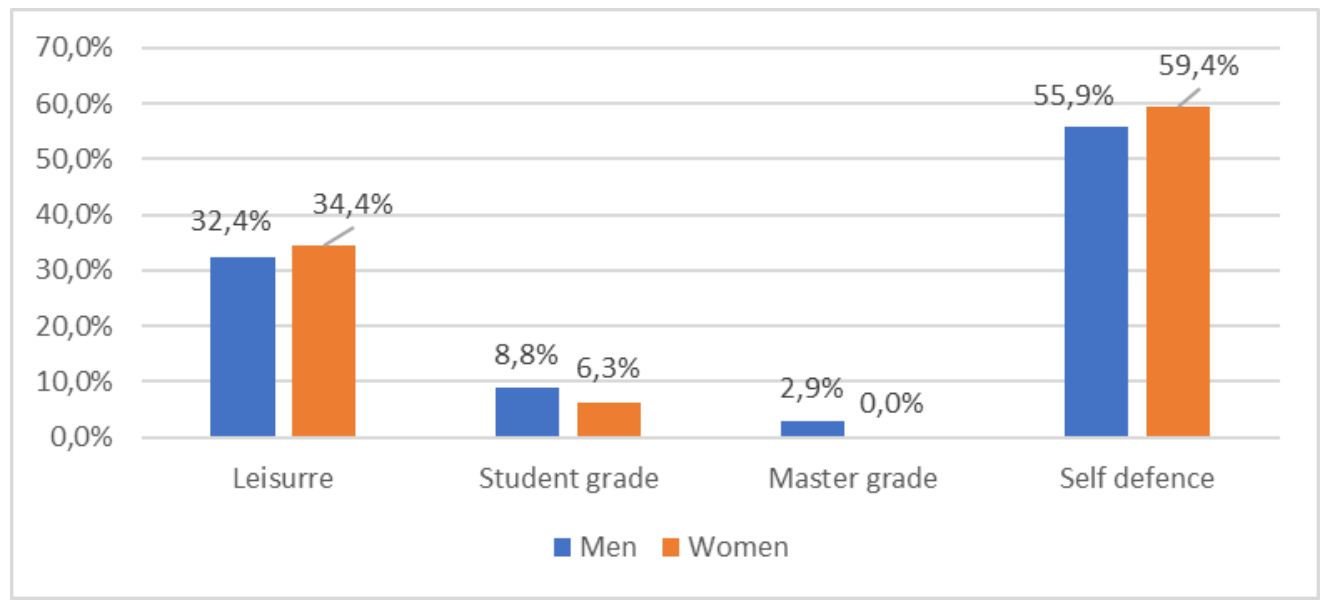

Figure 2. Technical level of judokas' respondents

Source: Study of authors

As obvious from the graph, vast majority of respondents practise judo as a self defence technique - this answer was given by $55.9 \%$ of men and $59.4 \%$ of women. Merely $2.9 \%$ of respondents have achieved a master grade.

Next questions focused on dietary habits of respondents. Following question aims to finding whether and to which extent the respondents are mindful of a balanced diet. Results are summarized in figure 3 .

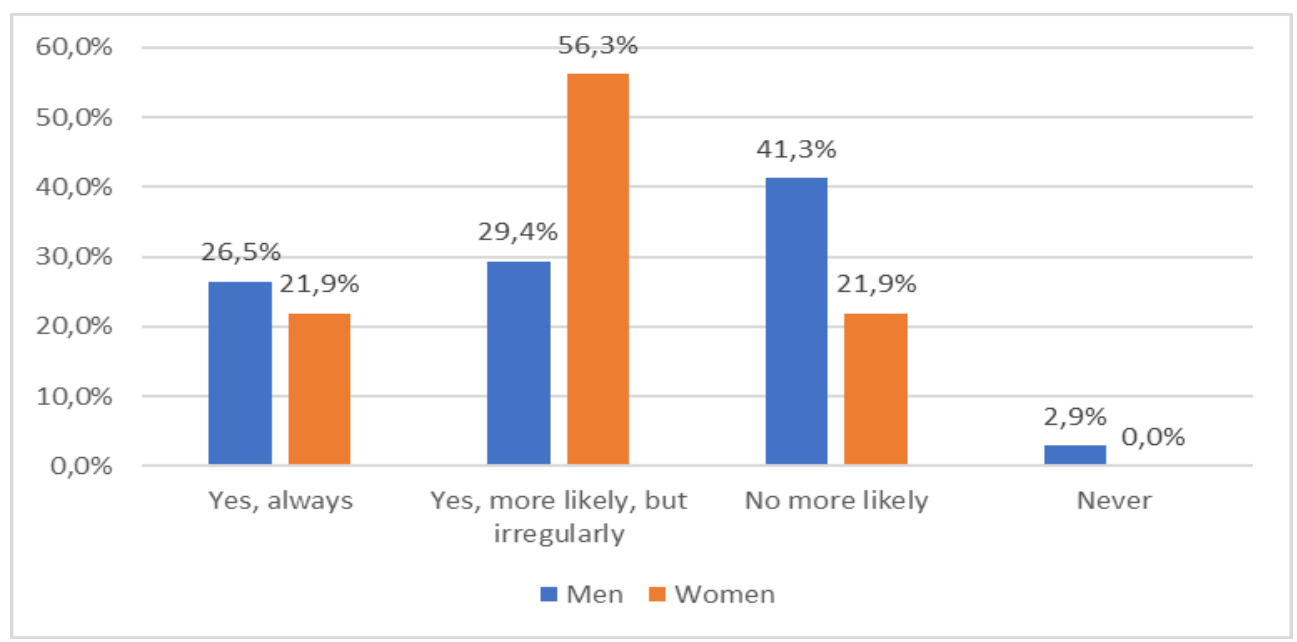

Figure 3. Respondents care about balanced diet

Source: Study of athors 
$26.5 \%$ of men and $21.9 \%$ of women always pay attention to well balanced diet. Most respondents answered that they care about balanced diet rather irregularly (29.4\% of men and $56.3 \%$ of women gave this answer). No woman and only $3 \%$ of men admitted that they never consider about balanced diet.

Next question asked whether in their daily diet, respondents adjust to specific energy needs for sportspeople. Answers are given in figure 4.

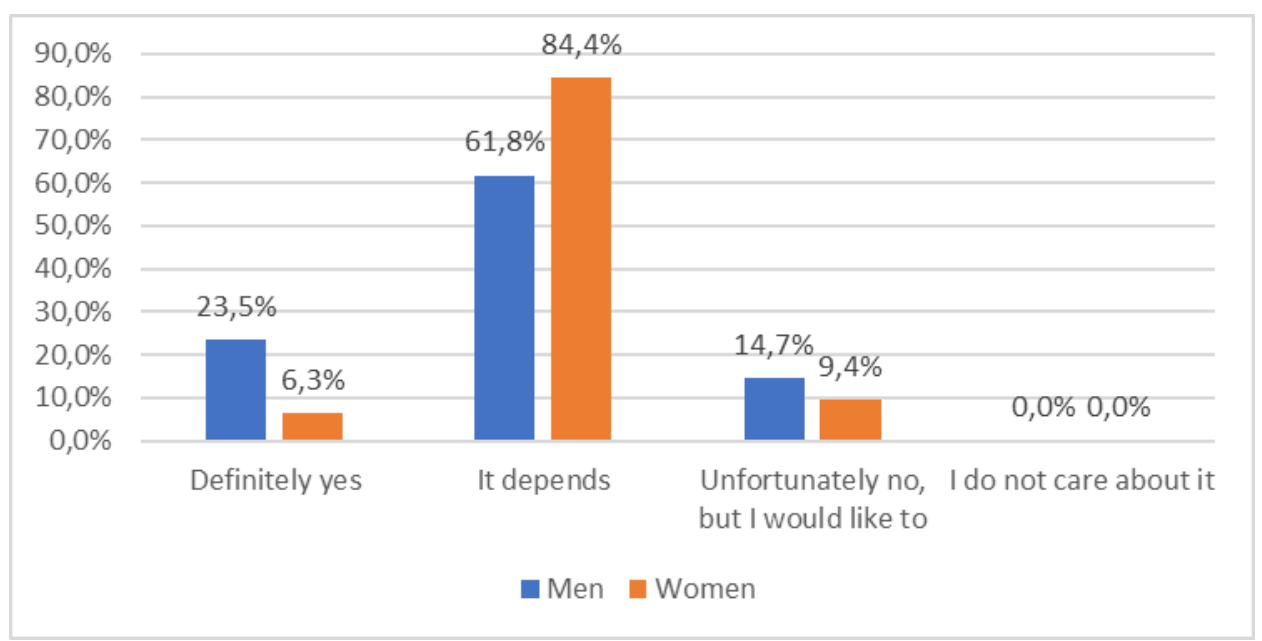

Figure 4. Adjustment to energy income for sportspeople in respondents' diet Source: Study of authors

The highest number of respondents claims that they always respect specific need for energy income $-61.8 \%$ of men and $84.4 \%$ of women. $14.7 \%$ of men and $9.4 \%$ of women reported that they do not consider specific need for energy income for sportspeople, but they would be happy to do so. This might be either because of impossibility to prepare all meals at home or lack of information on their daily energy income and to have it under control. None of the respondents answered that they do not care about specific nutritional needs of sportspeople.

Question asking whether judokas are aware of their daily energy income is directly connected with the previous one. Responses are shown in figure 5. 


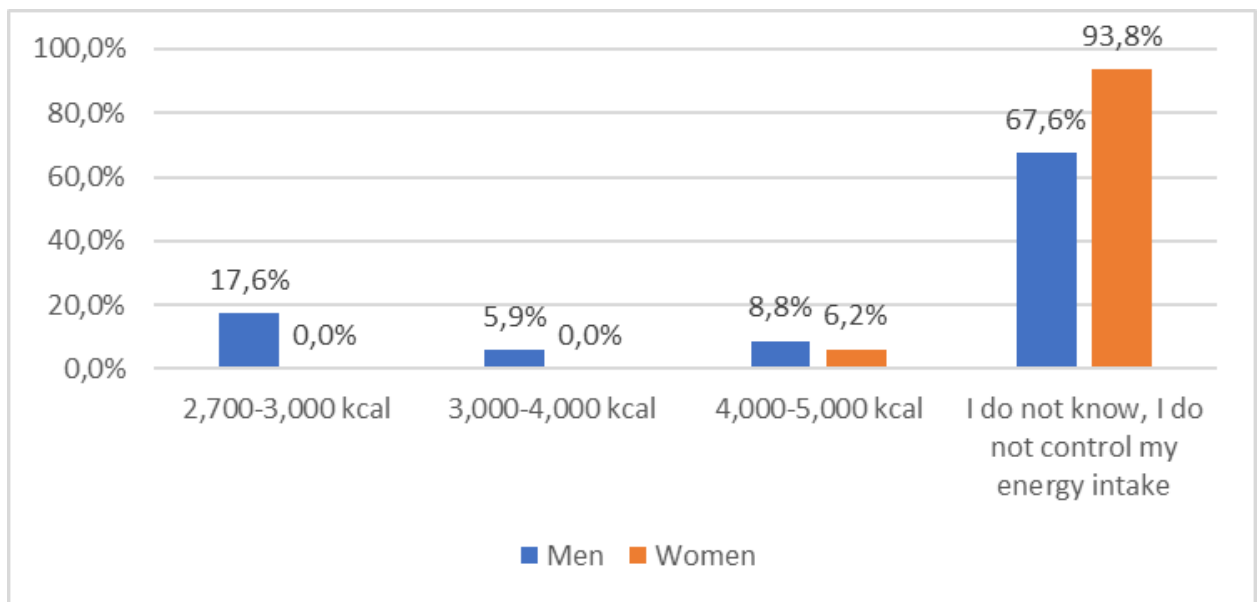

Figure 5. Daily energy income of judokas

Source: Study of authors

Despite the fact that in previous graph 4 merely $14.7 \%$ of men and $9.4 \%$ of women admitted that they do not consider specific energy income for sportspeople, and 61.8 $\%$ of men and $84.4 \%$ of women reported that they consider it sometimes, results summarized in figure 5 do not actually correspond with results of figure 4 . These show that $67.5 \%$ of male and $93.8 \%$ of female respondents do not control calorific value of their food at all - they ticked the option "I do not know, I do not control my energy intake". Other respondents are of the opinion that their energy income is lower than recommended for judokas, which is 5,680 kcal (see chapter Nutrition of judokas) (Juř́ḱková et Nguyen, at print).

As in other combat sports, many judo athletes try to reduce their body mass to have some physical advantage over opponents (Franchini et al., 2012) or due to psychological reasons, as feeling himself or herself as a real athlete or to perceive an increased focus and commitment to competitive goals (Pettersson et al., 2012; Pettersson et al., 2013). Evidence shows that this behaviour is found in males (Brito et al., 2012; Mendes et al., 2013), females (Boisseau et al., 2005; Kowatari et al., 2001) and in studies investigating both genders (Artioli et al., 2010a; Fabrini et al., 2010; Prouteau et al., 2006; Prouteau et al., 2007), from local to national level (Artioli et al, 2010b; Boisseau et al., 2005), for international level (Kowatari et al., 2001; Prouteau et al., 2006; Prouteau et al., 2007) and for mixed competitive levels (Brito et al., 2012; Fabrini et al., 2010), and it is experienced form very early ages such as 12 years (Artioli et al., 2010b; Brito et al., 2012; Escobar-Molina, 2014).

Last two questions aimed to finding whether the examined judokas use dietary supplements, and which. Answers to question aiming nutritional supplements are summarized in figure 6 , and figure 7 show answers to question aiming at vitamins and minerals. 


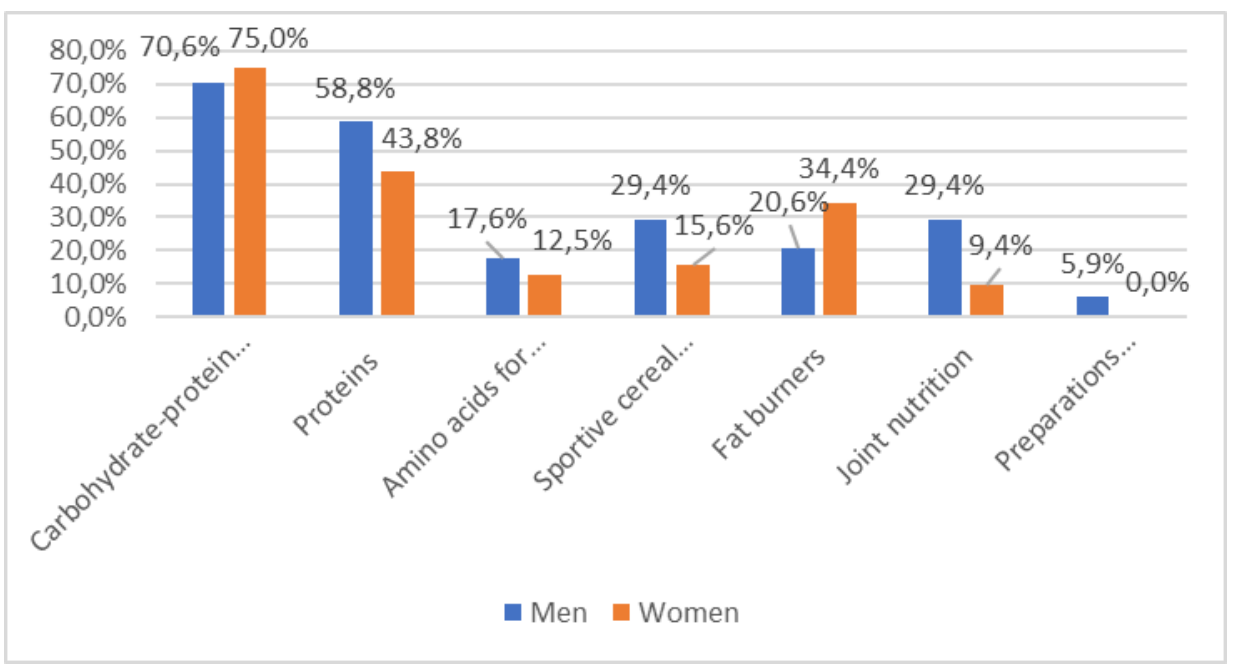

Figure 6. Usage of specific nutritional supplements by examined judokas

Source: Study of authors

Legend:

Carbohydrate protein.... = carbohydrate-protein conjugates

Proteins

Amino acids for ..... = Amino acids for muscle growth and regeneration

Sportive cereal ..... = Sportive cereal mixtures and bars

Fat burners

Joint nutrition

Preparations ..... = Preparations enhancing regeneration

It is obvious from figure 6 that respondents who use nutritional supplements mostly prefer carbohydrate-protein conjugates - this option was selected by $70.6 \%$ of men and $75 \%$ of women. These preparations are reasonable source of energy (from carbohydrates) as well as building substances for muscle mass regeneration (from proteins). 


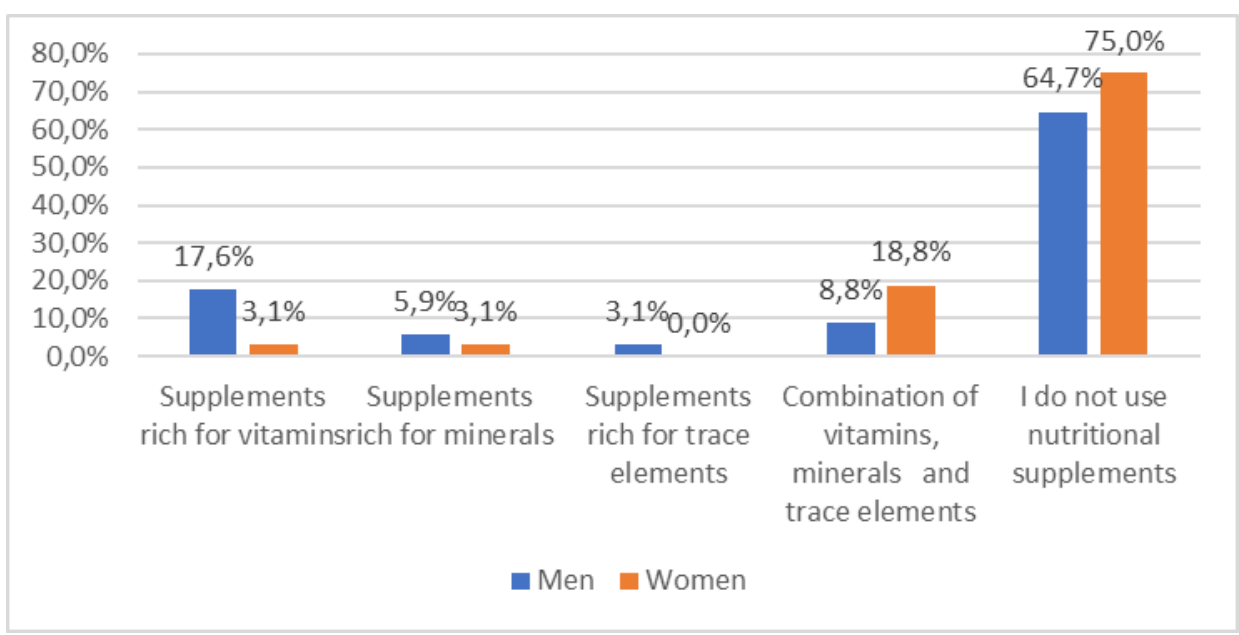

Figure 7. Usage of supplements with vitamins and minerals by examined judokas Source: Study of authors

As the graph shows, most respondents do not use supplements with vitamins and minerals - this answer was given by $64.7 \%$ of men and $75 \%$ of women. Other respondents, who use food supplements, mostly selected supplements rich for vitamins (17.6\% of men), while women typically preferred combination of vitamins, minerals and trace elements (Nguyen, 2017). From nutritional aspects, this combination can be highly recommended not only to judoka competitors, but to sportspeople in general.

Maughan (2014) claim the effects of vitamin and mineral supplementation on athletic performance have been studied in many types of athletes and most researchers have not reported beneficial effects. Knechtle with his colleagues (2008) examined the effect of vitamin and mineral supplementation prior to a multistage, ultra-endurance run on race performance at the 2006 Deutschlandlauf in Germany. In this race, athletes ran across Germany from north to south, running more than $1200 \mathrm{~km}$ over 17 consecutive stages. They studied 20 male ultra-endurance runners by asking them to first complete a questionnaire concerning their use of vitamin and mineral supplements 4 weeks prior to the race. Based on the questionnaire, the researchers reported that 6 runners consumed multivitamin, 5 consumed vitamin $\mathrm{E}$, 4 consumed vitamin C, 2 consumed vitamin B complex, 1 consumed folate, and 11 reported no vitamin supplement intake. 7 runners stated that they consumed a multimineral supplement, while 9 consumed magnesium, 5 consumed zinc, 3 consumed iron, 3 consumed calcium, and 8 reported no mineral supplementation use. Perhaps unsurprisingly, Knechtle with his colleagues (2008) reported no differences in performance between athletes who consumed vitamin and/or mineral supplements and those who reported no intake (Maughan, 2014). 


\section{Conclusions}

The aim of the paper was to find out eating habits of judokas from judo club in Holešov and students of programme Special Education of Security Bodies who practise combative sports including judo in University Campus in Brno-Bohunice. in the Czech Republic. The questionnaire survey was attended by 66 judokas in total, out of which there were 34 male $(52 \%)$ and 32 female $(48 \%)$ respondents. Women aged 20-25 years (average age in female group was 19.34), men also aged 20-25 years (average age in male group was 22.24). Majority of female respondents were students with non-sportive specialization, in men it is about a half (41\% of respondents). Majority of respondents were practiced judo as a self - defense technique - this answer was given by $55.9 \%$ of men and $59.4 \%$ of women. $26.5 \%$ of men and $21.9 \%$ of women always pay attention to well balanced diet. The highest number of respondents claims that they always respect specific need for energy income $-61.8 \%$ of men and $84.4 \%$ of women. Merely $14.7 \%$ of men and $9.4 \%$ of women admitted that they do not consider specific energy income for sportspeople, and $61.8 \%$ of men and $84.4 \%$ of women reported that they consider it sometimes. Respondents who use nutritional supplements mostly prefer carbohydrate-protein conjugates - this option was selected by $70.6 \%$ of men and $75 \%$ of women. Most respondents do not use supplements with vitamins and minerals - this answer was given by $64.7 \%$ of men and $75 \%$ of women.

\section{References}

Aloui, A., Chtourou, H., Briki, W., Tabben, M., Chaouachi, A., Souissi, N., Shephard, R. J., Chamari, K. (2016), „Rapid weight loss in the context of Ramadan observanceL recommendations for judokas", Biology of Sport, Vol. 33, Issue 4, pp. 407-4013. Doi: 10.5604/20831862.1224098.

Artioli, G. G., Gualano, B., Franchini, E., Batista, R. N., Polacow, V. O., Lancha, A. H. jr. (2009), „Physiological, performance, and nutritional profile of the Brazilian Olympic Wushu (kung-fu) team", Journal of Strength and Conditioning Research, Vol. 23, Issue 1, pp. 20-25.

Artioli G. G., Franchini, E., Nicastro, H., Sterkowicz, S., Solis, M. Y., Lancha, A. H. (2010), "The need of a weight management control program in judo: a proposal based on the successful case of wrestling", Journal of the International Society of Sports Nutrition, doi: 10.1186/1550-2783-7-15.

Artioli, G. G., Franchini, E., Nicastro, H., Sterkowicz, S., Solis, M. Y., Lancha, A. H. (2010a), "The need of a weight management control program in judo: a proposal based on the successful case of wrestling", Journal of the International Society of Sports Nutrition, Vol. 7. Retrieved frorm https://jissn.biomedcentral.com/track/pdf/10.1186/1550-2783-7-15 (accessed 14 January 2018).

Artioli, G. G., Gualano, B., Franchini, E., Scagliusi, F. B., Takesian, M., Fuchs, M., Lancha, A. H. jr. (2010b), "Prevalence, magnitude, and methods of rapid weight loss among judo competitors", Medicine and Science in Sports and Exercise, Vol. 42, Issue 3, pp. 436-442. PubMed doi: 
10.1249/MSS.0b13e3181ba8055.

Boguszewski, D., Adamczyk, J. G., Buda, M., Białoszewski, D. (2013), "The estimation of health-related behaviours of male judokas", Journal of Combat Sports and Martial Arts, Vol. 4, Issue 2 (2), pp. 179-183.

Boissseau, N., Vera-Perez, S., Poortmans, J. (2005), "Food and fluid intake in adolescent female judo athletes before competition", Pediatric Exercise Science, Vol. 17, Issue 1, pp. 62-71.

Brito, C. J., Roas, A., F., Brito I. S., Marins, J. C., Cordova, C., Franchini, E. (2012), "Methods of body mass reduction by combat sport athletes", International Journal of Sport Nutrition and Exercise Metabolism, Vol. 22, Issue 2, pp.89-97.

Costarelli, V., Stamou, D. (2009), „Emotional intelligence, body image and disordered eating attitudes in combat sport athletes", Journal of Exercise Science \& Fitness, Vol. 7, Issue 2, pp. 104-111.

Escobar-Molina, R., Rodriguez-Ruiz, S., Gutierrez-Garcia, C. Franchini, E. (2015), "Weight Loss and Psychological-Ralated States in High-Level Judo Athletes", International Journal of Sport Nutrition and Exercise Metabolism, Vol. 25, pp. 110-118.

Fabrini, S. P., Brito, C. J., Mendes, E. L., Sabarense, C. M., Marins, J. C. B., Franchini, E. (2010), "Práticas de redução de massa corporal em judokas nos períodos pré-competitivos", Revista Brasilerira de Educação Física e Esporte, Vol. 24, Issue 2, pp. 165-177. Doi: 10.1590/S1807-55092010000200002.

Filaire, E., Rouveix, M., Pannafleux, C., Ferrand, C. (2007), "Eating attitudes, perfectionism and body-esteem of elite male judoists and cyclists. Journal of Sports Science \& Medicine, Vol. 6, Issue 1, pp. 50-57. Retrieved from https://www.jssm.org/hf.php?id=jssm-06-50.xml (accessed 24 February 2018).

Fortes, L. S., Ferreira, M. E. C. (2011), "Comparison of body dissatisfaction and inappropriate eating behaviour in adolescent athletes of different sports", Revista Brasileira de Educacao Fisica e Esporte, Vol. 25, Issue 4, pp. 707-716. Retrieved from http://dx.doi.org/10.1590/S1807-55092011000400014 (accessed 24 February 2018).

Fortes, L. S., Kakeshita, I. S., Almeida, S. S., Gomes, A. R., Ferreira, M. E. C. (2014), "Eating behaviours in youths: A comparison between female and male athletes and non-athletes", Scandinavian Journal of Medicine \& Science in Sports. $\quad$ Retrieved from https://onlinelibrary.wiley.com/doi/epdf/10.1111/sms.12098 (accessed 24 February 2018).

Franchini, E., Del Vecchio, F. B., Matsushigue, K. A., Artioli, G. G. (2011a), "Physiological profiles of elite judo athletes", Sports Medicine, Vol. 41, Issue 2, pp. 147-166.

Franchini, E., Huertas, J. R., Sterkowicz, S., Carratala, V., Gutierrez-Garcia, C., Escobar-Molina, R. (2011b), "Anthropometrical profile of elite Spanish Judoka: Comparative analysis among ages”, Archives of Budo, Vol. 7, Issue 4, pp. 239-245.

Franchini, E., Brito, C. J., Artioli, G. G. (2012), "Weight loss in combat sports: physiological, psychological and performance effects", Journal of the International Society of Sports Nutrition, Vol. 9. Retrieved from 
http://www.jissn.com/content/9/1/52 (accessed 8 February 2018).

Franchini, E., Brito, C. J., Artioli, G. G. (2012), "Weight loss in combat sports" physiological, psychological and performance effects", Journal of the International Society of Sports Nutrition, Vol. 9. Retrieved from https://doi.org/10.1186/1550-2783-9-52 (accessed 24 February 2018).

Garber, C. E., Blissmer, B., Deschenes, M. R., Franklin, B. A., Lamonte, M. J., Lee, I. M., Nieman, D. C., Swain, D. P. (2011), "Quantity and Quality of Exercise for Developing and Maintaining Cardiorespiratory, Musculoskeletal, and neuromotor Fitness in Apparently Healthy Adults: Guidance for Prescribing exercise", Medicine \& Science in Sports \& Exercise, Vol. 43, Issue 7, pp. 13341359. Doi: 10.1249/MSS.0b013e318213fefb.

Hoare, S. (2010), A history of judo, Yamagi Books, London.

International Judo Federation - www.ijf.org (accessed 7 February 2018).

International Judo Federation, Judo Corner - Judo History. Retrieved from www.intjudo.eu/Judo_Corner (accessed 7 February 2018).

International Judo Federation Aims and Missions. Retrieved from http://99e89a50309ad79ff91d-

082b8fd5551e97bc65e327988b444396.r14.cf3.rackcdn.com/up/2017/12/AIMS -MISSIONS-1514465569-1514465569.pdf. (accessed 8 February 2018).

Judo. http://www.judo-3.banda.cz/clanek/13982/pasky/ (accessed 8 February 2018).

Julio, U. F., Takito, M. Y., Mazzei, L., Miarka, B., Sterkowicz, S., Franchini, E. (2011), "Tracking 10-year competitive winning performance of judo athletes across age groups", Perceptual and Motor Skills, Vol. 113. Issue 1, pp. 139149.

Jurikova, J., Nguyen, D., H. Knowledge of judokas competitors on proper nutrition. In print.

Kalina, R. M., Kruszewski, A., Jagiełło, W., Włoch, G. (2003), Combat sports propaedeutics - basics of judo, Wydawnictwo AWF, Warszawa.

Kalina, R. M. (1997), Sporty walki i trening samoobrony w edukacji obronnej młodzieży, PTNKF, Warszawa.

Kalina, R. M. (2000), Teoria sportów walki. COS, Warszawa.

Kazemi, J., Shearer, H., Choung, Y. S. (2005), "Pre-competition habits and unjuries in Taekwondo athletes", BMC Musculoskeletal Disorders, Vol. 6. Retrieved from https://bmcmusculoskeletdisord.biomedcentracom/articles/10.1186/14712474-6-26 (accessed 8 February 2018).

Kingham, R. B., Gorenflo, E. W. (2001), "Weight loss methods of high school wrestlers", Medicine \& Science in Sports \& Exercise, Vol. 33, Issue 5, pp. 810813.

Knechtle, B., Knechtle, P., Schulze, I., Kohler, G. (2006), "Vitamins, minerals and race performance in ultra-endurance runners - Deutschlandlauf 2006", Asia Pacific Journal of Clinical Nutrition, Vol. 17, Issue 2, pp. 194-198.

Kowatari, K., Umeda, T., Shimoyama, T., Nakaji, S., Yamamoto, Y., Sugawara, K. (2001), "Exercise training and energy restriction decrease neutrophil phagocytic activity in judoists", Medicine and Science in Sports and Exercise, Vol. 33, Issue 4, pp. 519-524.

Malliaropoulos, N., Rachid, S., Korakakis, V., Fraser, S. A., Bikos, G., Maffulli, N., 
Angioi, M. (2017), "Prevalence, techniques and knowledge of rapid weight loss amongst adult british judo athletes: a questionnaire based study", Muscles, Ligaments and Tendons Journal, Vol. 7, Issue 3, pp. 459-466.

Maughan, R. J. (2014), Sports Nutrition. Wiley-Blackwell. Chicester, West Sussex. Mendes, S. H., Tritto, A. C., Guilherme, J. P. L. F., Solis, M. Y., Vieira, D. E., Franchini, E., Lancha, A. H. jr., Guilherme, G. A. (2013), "Effect of rapid weight loss on performance in combat sport male athletes: Does adaptation to chronic weight cycling play a role?", British Journal of Sports Medicine, Vol. 47, Issue 18, pp. 1155-1160.

Nguyen, D. H. (2017). Stravování zápasníků džúdó. [Bachelor's thesis]. Brno.

Pedro, J., Durbin, W. (2001), Judo techniques. Retrieved from http://eds.b.ebscohost.com/eds/pdfviewer/pdfviewer?vid=4\&sid=9f109db004ff-4220-83f4-6521a00fd8a6\%40sessionmgr101 (accessed 7 February 2018).

Petersson, S., Ekstrom, M. P., Berg, C. M. (2012), "The food and weight combat. A problematic fight for the elite combat sports athlete. Apetite, Vol. 59, Issue 2, pp. 234-242. PubMed doi: 10.1016/j.appet.2012.05.007.

Proteau, S., Benhamou, L., Courteix, D. (2006), "Relationship between serum leptin and bone markers during stable weight, weight reduction and weight regain in male and female judoists", European Journal of Endocrinology, Vol. 154, Issue 3, pp. 389-395. PubMed doi: 10.1530/eje.1.02103.

Proteau, S., Ducher, G., Serbescu, C., Benhamou, L., Courteix, D. (2007), “Gender differences in response to weight cycling in elite judoists. Biology of Sport, Vol. 24, Issue 2, pp. 91-104.

Pettersson, S., Ekstrom, M. P., Berg, C. M. (2013), "Practices of weight regulation among elite athletes in combat sports: a matter of mental advantage?", Journal of Athletic Training, Vol. 48, Issue 1, pp. 99-108.

Rosendahl, J., Bormann, B., Aschenbrenner, K., Aschenbrenner, F., Strauss, B. (2009), „Dieting and disordered eating in German High school athletes and non-athletes“, Scandinavian Journal of Medicine \& Science in Sports, Vol. 19, Issue 4, pp. 731-739.

Torstweit, M. K., Rosenvinge, J. H., Sundgot-Borgen, J. (2008), "Prevalence of eating disorders and predictive power of risk models in female athletes elite: a controlled study", Scandinavian Journal of Medicine \& Science in Sports, Vol. 48, Issue 1, pp. 108-118.

Villamon, M., Brown, D., Espartero, J., Gutierrez-Garcia, C. (2004), "Reflexive modernization and the disembedding of judo from 1946 to the 2000 Sidney Olympics", International Review for the Sociology of Sport, Vol. 39, Issue 2, pp. 139-156. Doi: 10.1177/1012690204043458. 